\title{
Jejunal mucosal morphometry in children with and without gut symptoms and in normal adults
}

\author{
FJ PENNA,* ID HILL, $\dagger$ D KINGSTON,* K ROBERTSON, \\ M SHINER*
}

From the *Intestinal Studies Group, Division of Clinical Sciences, the †Division of Computing and Statistics, Clinical Research Centre, and the $\ddagger$ Department of Histopathology, Northwick Park Hospital, Watford Road, Harrow, Middlesex HA1 3UJ, UK

SUMMARY Nineteen diagnostic peroral biopsy specimens from 18 children without diarrhoea, vomiting, or abdominal pain ('control' children) were compared with those taken from 23 children with diarrhoea of varying aetiology to establish the morphometric characteristics of jejunal mucosa in childhood. Comparison was also made with normal jejunal mucosa from adults. Statistical analysis of each characteristic individually showed no significant difference between the 'control' children and those with diarrhoea, but there were significant differences between the mucosae of 'control' children and those of adults: the villi tended to be shorter and the crypts longer in children. Thirtyseven per cent of specimens from the 'control' children showed a partial villous atrophy, that is, they were abnormal by adult criteria. Discriminant analysis of the features measured showed effective separation of the following groups: normal histology from partial villous atrophy in children, healthy adults from 'control' children, and normal histology in adults from normal histology in children.

Morphometric measurements of the jejunal mucosa obtained by peroral biopsy in adults have been exhaustively reported. The techniques employed have varied from simple measurements using linear scales and grids $^{1-9}$ to use of the Weibel template ${ }^{10}$ to measure surface-to-volume ratio ${ }^{11}$ and television image analysis. ${ }^{12} 13$ There have been fewer reports on jejunal morphometry in children. Jos ${ }^{14}$ and other authors ${ }^{15} 16$ used simple micrometer measurements, Risdon and Keeling ${ }^{17}$ the surface-to-volume ratio method of Dunnill and Whitehead, ${ }^{11}$ and Meinhard et al..$^{18}$ computer analysis of projections traced on to computer cards.

The validity of judging children's jejunal mucosae on adult morphological measurements is doubtful. This applies particularly to infants in whom the gut is exposed for the first time not only to postnatal colonisation but also to the influences of food and bacterial antigens which invoke the local immune response. Stereomicroscopic viewing of children's biopsies rarely shows the tall villi seen in normal adult biopsies, and ridges or even convolutions may be seen even when histology does not show gross architectural changes. Minor histological abnormalities are so common that the difference between

Accepted for publication 3 September 1980 'normal' appearances and a 'mild partial villous atrophy' becomes indistinct, $c f .{ }^{19}$ We have therefore made simple morphometric measurements on jejunal mucosa to ascertain the following points:

1 Are the measurements in children without gastrointestinal symptoms similar to those of adults?

2 Is the subjective grouping of children's biopsies into normal and partial villous atrophy clinically relevant, or should minor abnormalities be disregarded?

3 Is there a difference between the histological measurements in children without gastrointestinal symptoms and in those with chronic diarrhoea?

\section{Patients and controls}

Forty-one patients from whom adequate jejunal biopsies were obtained were referred by paediatricians over a number of years for routine biopsy to exclude small bowel disease when this was diagnostically relevant. This was carried out with the informed consent of the child's parent. The patients were grouped on clinical grounds into those without diarrhoea, vomiting, or abdominal pain at the time of investigation (18 patients) and those with diarrhoea of several weeks' standing ( 23 patients). The first group of patients (Table 1) is subsequently referred to as 
Table 1 'Control' children (without diarrhoea)

\begin{tabular}{|c|c|c|c|c|}
\hline \multirow[t]{2}{*}{ Diagnosis } & \multirow{2}{*}{$\begin{array}{l}\text { No. of } \\
\text { patients }\end{array}$} & \multirow[t]{2}{*}{ Range of age at biopsy } & \multicolumn{2}{|c|}{ No. of biopsies } \\
\hline & & & $N$ & $\boldsymbol{P V A}$ \\
\hline $\begin{array}{l}\text { Failure to thrive } \\
\text { Cow's milk protein intolerance on milkless diet } \\
\text { Normal (coeliac disease in family) } \\
\text { Diarrhoea in infancy (to exclude coeliac disease) } \\
\text { Rickets (normal serum } \mathrm{Ca}^{++} \text {) } \\
\text { Renal tubular acidosis } \\
\text { Incontinentia pigmenti } \\
\text { Crohn's disease + Still's } \\
\text { Weight loss? nutritional }\end{array}$ & $\begin{array}{l}6 \\
2 \\
3 \\
2 \\
1 \\
1 \\
1 \\
1 \\
1\end{array}$ & $\begin{array}{l}10 \mathrm{~m}-7 \mathrm{yr} 8 \mathrm{~m} \\
1 \mathrm{yr} 3 \mathrm{~m} \& 2 \mathrm{yr} 10 \mathrm{~m} \\
4 \mathrm{yr} 4 \mathrm{~m}, 10 \mathrm{yr} 6 \mathrm{~m}, 12 \mathrm{yr} 1 \mathrm{~m} \\
3 \mathrm{yr} 3 \mathrm{~m} \& 12 \mathrm{yr} 6 \mathrm{~m} \\
2 \mathrm{yr} 8 \mathrm{~m} \\
2 \mathrm{yr} 4 \mathrm{~m} \\
6 \mathrm{yr} 7 \mathrm{~m} \\
9 \mathrm{yr} \& 11 \mathrm{yr} 10 \mathrm{~m} \text { (2 biopsies) } \\
3 \mathrm{yr} 6 \mathrm{~m}\end{array}$ & $\begin{array}{l}3 \\
2 \\
3 \\
1 \\
1 \\
0 \\
1 \\
1 \\
0\end{array}$ & $\begin{array}{l}3 \\
0 \\
0 \\
1 \\
0 \\
1 \\
0 \\
1 \\
1\end{array}$ \\
\hline Total & \multicolumn{2}{|c|}{$18+1$ repeat biopsy } & 12 & 7 \\
\hline
\end{tabular}

Table 2 Children with persistent diarrhoea

\begin{tabular}{llll}
\hline No. of patients & Range of age at biopsy & \multicolumn{2}{l}{ No. of biopsies } \\
\cline { 2 - 3 } & & $N$ & $P V A$ \\
\hline $23^{*}$ & $\begin{array}{l}\text { 5m-10yr } 6 \mathrm{~m} \\
\text { Mean age } 2 \mathrm{yr} 4 \mathrm{~m}\end{array}$ & 12 & 11 \\
\hline
\end{tabular}

$\mathbf{N}=$ normal. $\quad$ PVA $=$ partial villous atrophy.

* Includes one child from whom Giardia lamblia was subsequently isolated.

'controls'. The clinical data of the second group are given in Table 2. Parasites or pathogens were not found in the jejunal juice and/or faeces of the diarrhoea group with the exception of one patient with Giardia lamblia. The average age of the 'control' patients was 5 years 5 months whereas that of the children with chronic diarrhoea was 2 years 4 months. The effect of this age difference is discussed later in the statistical analysis but is probably not important. The clinical category as well as the histological appearances of the biopsies had been established by one of us (MS), who was unaware of the morphometric measurements carried out independently by one of the other authors, with checks by two others. All patients with flat biopsies thought to be characteristic of coeliac disease were excluded. One patient in the 'control' group (Table 1) had two jejunal biopsies at an interval of two years and has been included in the statistical analysis as two independent patients. Other patients each had a single biopsy.

The children's biopsies were compared with those taken from seven healthy adult volunteers. In addition, we studied seven biopsies from adult patients which were judged to be normal histologically. The adult groups differed from each other in that the volunteers had deeper crypts, but the values for each group fell within the normal range established in this hospital $(68-160 \mu \mathrm{m})$. The aggregated adult biopsies are referred to as 'histologically normal'.

\section{Methods}

Only well orientated sections from jejunal biopsies were examined. The morphometric analysis of the sections was performed using a microscope fitted with a Dynascope (model 7A) viewing head. An eyepiece graticule was placed in a $\times 10$ focusing eyepiece, which was fitted with the Dynascope correction collar. The eyepiece graticule scale was calibrated with a stage micrometer. A single division of the graticule scale was found to correspond to $\mathbf{5 2}$ $\mu \mathrm{m}$ when used with a $\times 10$ objective and $13 \mu \mathrm{m}$ when used with a $\times 40$ objective. Subsequently, a $1 \mathrm{~cm}^{2}$ eyepiece graticule divided into 100 small squares was fitted into the $\times 10$ focusing eyepiece together with the correction collar. Using a stage micrometer the grid was calibrated and found to have an area of $0.06 \mathrm{~mm}^{2}$ when the $\times 40$ objective was selected.

\section{VILLUS HEIGHT}

Twelve villi were measured in each biopsy from the tip to the villus-crypt junction.

\section{CRYPT DEPTH}

Twelve crypts were measured in a similar way to the villi.

\section{ENTEROCYTE HEIGHT}

Ten enterocytes were measured from the middle portion of villi. Only one cell was measured from the side of any villus. Our observations confirm the experience of others ${ }^{20}$ that variations in cell height make it difficult to get accurate values with this technique.

\section{THELIOLYMPHOCYTES (INTRAEPITHELIAL LYMPHOCYTES)}

The number of lymphocytes lying within the epithelium of villi for a total of 500 enterocytes was counted.21 The lowest quarter of each villus was 
excluded from the count. Results were expressed as theliolymphocytes per 100 enterocytes.

\section{INFLAMMATORY CELLS}

These were counted in two areas of the lamina propria: in the villi (villus inflammatory cells) and between the muscularis mucosae and villus-crypt junction (crypt-associated inflammatory cells). ${ }^{22}{ }^{23}$ The number of inflammatory cells occurring within 50 small grid squares was counted and expressed as the number of cells per square millimetre of lamina propria.

\section{STATISTICAL METHODS}

The significance of differences between the arithmetic means of individual variables (villus height, etc) was assessed using Student's $t$ test (two-tailed). Results and discussion using this method are headed 'Simple analysis'. To determine whether, if all the variables were considered together, the biopsies from different patients or histological categories could be separated into different groups discriminant functions were used. ${ }^{24}$

\section{Results}

SIMPLE ANALYSIS

Tables 1 and 2 show that the incidence of partial villous atrophy in the control and diarrhoea group of biopsies was $7 / 19$ and $11 / 23$ respectively. This difference is not significant $(P=0.54$ exact test).

Table 3 shows the values of the measurements for the seven healthy volunteers, 18 'control' children (one biopsied twice), and 23 children with persistent

Table 3 Morphometric measurements for patient categories: mean values and $\mathrm{P}$ of differences (standard deviations in parentheses)

\begin{tabular}{|c|c|c|c|c|c|}
\hline \multirow{3}{*}{$\begin{array}{l}\text { Number of biopsies } \\
\text { Mean age }\end{array}$} & \multicolumn{2}{|c|}{$\begin{array}{l}\text { Healthy } \\
\text { adult } \\
\text { volunteers }\end{array}$} & \multicolumn{2}{|l|}{$\begin{array}{l}\text { 'Control' } \\
\text { children }\end{array}$} & \multirow{2}{*}{$\begin{array}{l}\begin{array}{l}\text { Diarrhoea } \\
\text { childrer. }\end{array} \\
23\end{array}$} \\
\hline & 7 & & 19 & & \\
\hline & $\begin{array}{l}48 y r \\
(9 y r)\end{array}$ & & $\begin{array}{l}5 y r 5 m \\
(4 y r 0 m)\end{array}$ & $P=0.004$ & $\begin{array}{l}42 \mathrm{yr} 4 \mathrm{~m} \\
(2 \mathrm{yr} 4 \mathrm{~m})\end{array}$ \\
\hline Villus height $(\mu \mathrm{m})$ & $\begin{array}{l}372 \\
(48)\end{array}$ & $P=0.006$ & $\begin{array}{l}304 \\
(52)\end{array}$ & $P=0.3$ & $\begin{array}{l}281 \\
(80)\end{array}$ \\
\hline Crypt depth $(\mu \mathrm{m})$ & $\begin{array}{l}132 \\
\text { (13) }\end{array}$ & $P=0.03$ & $\begin{array}{l}167 \\
(38)\end{array}$ & $P=0.3$ & $\begin{array}{l}178 \\
(25)\end{array}$ \\
\hline Ratio (VH/CD) & $\begin{array}{l}2 \cdot 83 \\
(0 \cdot 37)\end{array}$ & $P<0.0001$ & $\begin{array}{l}1 \cdot 88 \\
(0 \cdot 40)\end{array}$ & $P=0.08$ & $\begin{array}{l}1 \cdot 62 \\
(0 \cdot 53)\end{array}$ \\
\hline $\begin{array}{l}\text { Enterocyte height } \\
(\mu \mathrm{m})\end{array}$ & $\begin{array}{l}33 \cdot 4 \\
(1 \cdot 6)\end{array}$ & $P=0.5$ & $\begin{array}{l}32 \cdot 3 \\
(3 \cdot 8)\end{array}$ & $P=0.6$ & $\begin{array}{l}31 \cdot 5 \\
(5 \cdot 5)\end{array}$ \\
\hline $\begin{array}{l}\text { Theliolymphocytes } \\
\text { per } 100 \text { enterocytes }\end{array}$ & $\begin{array}{l}17 \cdot 7 \\
(4 \cdot 9)\end{array}$ & $P=0.5$ & $\begin{array}{l}19 \cdot 1 \\
(4 \cdot 3)\end{array}$ & $P=0 \cdot 2$ & $\begin{array}{l}22 \cdot 2 \\
(9 \cdot 2)\end{array}$ \\
\hline $\begin{array}{l}\text { Inflammatory cells } \\
\text { (villi) per } \mathrm{mm}^{2}\end{array}$ & $\begin{array}{l}10700 \\
(1900)\end{array}$ & $P=0.05$ & $\begin{array}{l}13000 \\
(2700)\end{array}$ & $P=0.3$ & $\begin{array}{l}13800 \\
(2400)\end{array}$ \\
\hline $\begin{array}{l}\text { Inflammatory cells } \\
\text { (crypts) per } \mathrm{mm}^{2}\end{array}$ & $\begin{array}{l}13300 \\
(1300)\end{array}$ & $P=0.07$ & $\begin{array}{l}15000 \\
(2200)\end{array}$ & $P=0.06$ & $\begin{array}{l}16700 \\
(3400)\end{array}$ \\
\hline
\end{tabular}

$\mathrm{VH}=$ villus height $\mathbf{C D}=$ crypt depth.

The $P$ values were obtained using Student's $t$ test. diarrhoea. There was no significant difference between the mean values of any of these measurements for the 'control' and diarrhoea groups of children, but the villus height/crypt depth (VH/CD) ratio and the inflammatory cells (crypt) were near the borderline of significance $(P=0.08$ and 0.06 respectively). More detailed analysis (see later) suggested that the significant age difference between the groups was not important. When 'control' children were compared with healthy adults significant differences could be shown in villus height, crypt depth, VH/CD, and the number of villus inflammatory cells.

Table 4 compares the measurements for adult and child biopsies graded subjectively as normal $(\mathrm{N})$ or partial villous atrophy (PVA). It is therefore a description in morphometric terms of the histological categories $\mathbf{N}$ as applied to children and adults and PVA as applied to children. When the $24 \mathrm{~N}$ child biopsies were compared with the 14 adult biopsies the difference in villus height was just statistically significant, but highly significantly different values were obtained for crypt depth and VH/CD. Comparison of the $24 \mathrm{~N}$ child biopsies with the 18 PVA child biopsies confirmed the subjective histological grading with significant differences in villus height, enterocyte height, and inflammatory cell count (villi only). The crypt depth measurements showed little difference. A scatter diagram (not presented here) for all the children's biopsies showed no obvious correlation between villus height and crypt depth, and the highly significant difference in $\mathrm{VH} / \mathrm{CD}$ must be due to the villus height.

The measurements of these children's biopsies were also grouped so as to compare the categories $\mathbf{N}$

Table 4 Morphometric measurements for histological categories normal and partial villous atrophy

\begin{tabular}{|c|c|c|c|c|c|}
\hline & $\begin{array}{l}\text { Subject } \\
\text { normal } \\
\text { histolog } \\
\text { (adults) }\end{array}$ & tively & $\begin{array}{l}\text { Subjective } \\
\text { normal } \\
\text { histology } \\
\text { (children) }\end{array}$ & vely & $\begin{array}{l}\text { Partial } \\
\text { villous } \\
\text { atrophy } \\
\text { (children) }\end{array}$ \\
\hline $\begin{array}{l}\text { No. of biopsies } \\
\text { Mean age }\end{array}$ & $\begin{array}{l}14 \\
46 y r \\
(16 y r)\end{array}$ & & $\begin{array}{l}24 \\
4 y r 3 m \\
(3 y r 7 m\end{array}$ & $\mathbf{P}=0.3$ & $\begin{array}{l}18 \\
3 \mathrm{yr} 0 \mathrm{~m} \\
(3 \mathrm{yr} 3 \mathrm{~m})\end{array}$ \\
\hline Villus height $(\mu \mathrm{m})$ & $\begin{array}{l}368 \\
(59)\end{array}$ & $P=0.04$ & $\begin{array}{l}332 \\
(45)\end{array}$ & $P<0.0001$ & $\begin{array}{l}237 \\
(57)\end{array}$ \\
\hline Crypt depth $(\mu \mathrm{m})$ & $\begin{array}{l}119 \\
(18)\end{array}$ & $P<0.0001$ & $\begin{array}{l}169 \\
(28)\end{array}$ & $P=0.4$ & $\begin{array}{l}178 \\
(36)\end{array}$ \\
\hline Ratio (VH/CD) & $\begin{array}{l}3 \cdot 17 \\
(0 \cdot 80)\end{array}$ & $P<0.0001$ & $\begin{array}{l}2.00 \\
(0.35)\end{array}$ & $P<0.0001$ & $\begin{array}{l}1 \cdot 39 \\
(0 \cdot 43)\end{array}$ \\
\hline $\begin{array}{l}\text { Enterocyte height } \\
(\mu \mathrm{m})\end{array}$ & $\begin{array}{l}33 \cdot 6 \\
(2 \cdot 8)\end{array}$ & $P=0.6$ & $\begin{array}{l}34 \cdot 1 \\
(3 \cdot 4)\end{array}$ & $P=0.0002$ & $\begin{array}{l}28 \cdot 9 \\
(4 \cdot 7)\end{array}$ \\
\hline $\begin{array}{l}\text { Theliolymphocytes } \\
\text { per } 100 \\
\text { enterocytes }\end{array}$ & $\begin{array}{l}18 \cdot 9 \\
(4 \cdot 2)\end{array}$ & $P=0.7$ & $\begin{array}{l}19 \cdot 8 \\
(7 \cdot 7)\end{array}$ & $P=0.3$ & $\begin{array}{l}22 \cdot 2 \\
(7 \cdot 3)\end{array}$ \\
\hline $\begin{array}{l}\text { Inflammatory cells } \\
\text { (villi) per } \mathrm{mm}^{2} \\
\text { Inflammatory cells } \\
\text { (crypts) per } \mathrm{mm}^{2}\end{array}$ & $\begin{array}{l}12000 \\
(2100) \\
14100 \\
(2000)\end{array}$ & $\begin{array}{l}P=0.3 \\
P=0.07\end{array}$ & $\begin{array}{l}12700 \\
(2200) \\
15500 \\
(2400)\end{array}$ & $\begin{array}{l}P=0.04 \\
P=0.3\end{array}$ & $\begin{array}{l}14400 \\
(2700) \\
16500 \\
(3700)\end{array}$ \\
\hline
\end{tabular}


and PVA within the 'control' and diarrhoea children, and to compare the 'control' and diarrhoea children within the categories $\mathbf{N}$ and PVA. The $\mathbf{N}$ category appeared similar in the two patient groups, but the PVA category for the diarrhoea children had shorter villi and more theliolymphocytes than for the control children, though these differences were significant only between $5 \%$ and $10 \%$. In the diarrhoea (but not the 'control') group, PVA tended to be found in the younger patients.

\section{DISCRIMINANT ANALYSIS}

In order to show whether simultaneous consideration of all measurements gave better discrimination into groups the data were analysed by discriminant analysis. The inflammatory cell counts used in the adult groups were those for the villi only.

This statistical technique has become readily available only with the use of computers and is therefore still not generally familiar. The computer, suitably programmed, constructs mathematical expressions (the canonical variables) of the form $a x_{1}+b x_{2}+\ldots .$. where $x_{1}, x_{2}$ are the different measurements (in this instance villus height, crypt depth, and so on). The coefficients $a, b, \ldots$ are calculated so as to weight the contributions of the different measurements, the requirement being that the canonical variable should separate the biopsies as well as possible into groups. We consider this to be an important approach to handling the results of histological measurements. It is only rarely that a single measurement can be used to determine a diagnosis, and the canonical variable provides a way of combining all the measurements together, each being given its appropriate weighting. In this study we have not applied the canonical variables to fresh data, and it must be emphasised that they are likely to work less well on such data than on the data from which they are derived, particularly as the samples we have analysed are small. A discussion of the use of this method in a medical context is given by Fraser et al. ${ }^{25}$

Analysis of the 42 children's biopsies showed that the morphometric studies gave a separation into groups (with some overlap) corresponding to the classification of $\mathrm{N}$ and PVA (Fig. 1, horizontal scale). A dividing line at -2.30 would have $4 \mathrm{Ns}$ to the right and 2 PVAs to the left of it, but the misclassified ones are all close to the dividing line. This was mainly due to measurement of villus height (mean of $332 \mu \mathrm{m}$ in $\mathrm{N}, 237 \mu \mathrm{m}$ in PVA; coefficient -0.89 ). Villus height measurements did not provide a firm classification (ranges: N, 259-411; PVA, 110-328), but a dividing point at $285 \mu \mathrm{m}$ would classify only 3 PVAs among the Ns, and 4 Ns among the PVAs, that is, only one more biopsy was misclassified than when discriminant analysis was used. However, only three

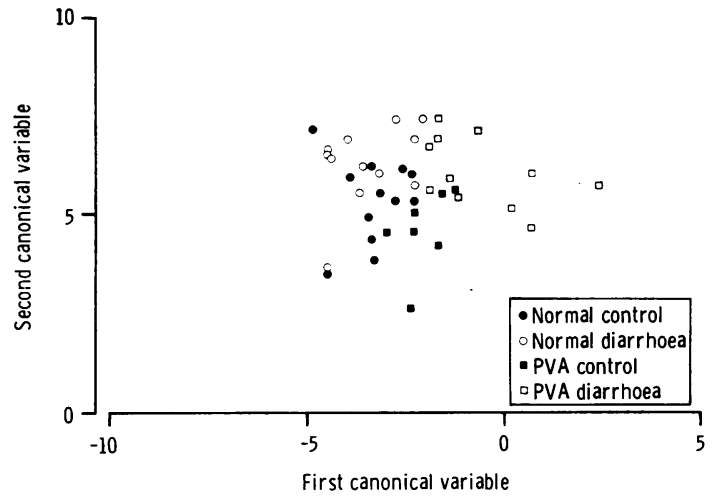

Fig. 1 Canonical analysis of measurements on children.

First canonical variable $=$

$-0.0184 \mathrm{~V}+0.0129 \mathrm{C}-0.0429 \mathrm{E}+0.0379 \mathrm{~T}$

$+0.0000311 \mathrm{I}_{\mathrm{v}}+0.0000514 \mathrm{I}_{\mathrm{c}}+0.0139 \mathrm{~A}$

Second canonical variable $=$

$0.00509 \mathrm{~V}-0.00657 \mathrm{C}+0.0792 \mathrm{E}+0.0686 \mathrm{~T}$

$-0.0000625 I_{v}+0.000206 I_{c}-0.279 A$

where $\mathrm{V}=$ villus height $(\mu \mathrm{m})$

$\mathrm{C}=$ crypt depth $(\mu \mathrm{m})$

$\mathrm{E}=$ enterocyte height $(\mu \mathrm{m})$

$\mathrm{T}=$ theliolymphocytes per 100 enterocytes

$\mathrm{I}_{\mathrm{v}}=$ inflammatory cells (villi) per $\mathrm{mm}^{2}$

$\mathrm{I}_{\mathrm{c}}=$ inflammatory cells (crypts) per $\mathrm{mm}^{2}$

$\mathrm{A}=\operatorname{age}($ years $)$

of the six biopsies misclassified by the discriminant analysis were also misclassified using villus height alone. Since the canonical variable uses all available information, it seems likely that it gives the better result. Crypt depth (coefficient 0.41) made the next biggest contribution, but neither VH/CD and still less crypt depth alone gave good discrimination between $\mathrm{N}$ and PVA.

In summary, the canonical variable gave good, though not complete, separation of $\mathrm{N}$ from PVA. Villus height measurements alone did nearly as well, but other measurements, including $\mathrm{VH} / \mathrm{CD}$, did not.

The separation into 'with diarrhoea' or 'without diarrhoea' ('control') could not satisfactorily be brought about by discriminant analysis any more than by the simpler analysis discussed earlier. If in Fig. 1 a discriminatory line were drawn at 5.70 on the vertical scale, there would be five 'control' patients above it and six diarrhoea patients below. In contrast to the separation for N and PVA, the misclassified patients were often a long way from their appropriate group. This partial separation was due to age of patient, crypt inflammatory cells, and theliolymphocytes, in that order (coefficients $-0.89,+0.61$, and +0.51 respectively). The largest correlation with age in the 'within groups' correlation matrix was -0.35 with crypt depth. The age contribution to the 
separation is therefore probably not very important. Also the significant difference in ages between the 'control' and diarrhoea groups in Table 3 is unlikely to have affected the analysis of the results given in that table. There were only two correlations greater than $0 \cdot 35$, namely, villus inflammatory cells with crypt inflammatory cells $(0.44)$ and villus height with enterocyte height $(0 \cdot 37)$, both positive.

Two comparisons were made between adults and children. The first was to compare the seven healthy adult volunteers with the 19 'control' children. In this comparison, only moderately good separation was found (Fig. 2). This was due to villus height

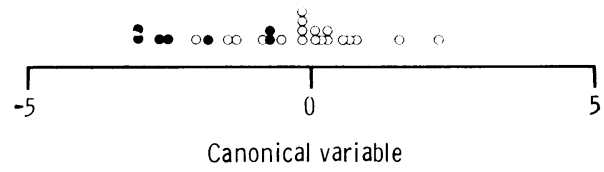

Fig. 2 Comparison of healthy volunteer adults with 'control' children.

Canonical variable $=-0.0167 \mathrm{~V}+0.0208 \mathrm{C}-0.00312 \mathrm{E}$

$+0.0458 \mathrm{~T}+0.0000621 \mathrm{I}$

children; 1 adults

(coefficient -0.85) and crypt depth (coefficient +0.71 ) in similar amounts. A $\mathrm{VH} / \mathrm{CD}$ ratio of, say, 2.40 did nearly as well as the canonical variable in separating the groups. Examination of the withingroup correlation matrix showed that although as a group the children had shorter villi and deeper crypts than the adults, within the groups there was a positive (though weak) correlation between villus height and crypt depth of 0.31 (that is, longer villi tended to be associated with deeper crypts). A weak positive correlation of villus height with crypt depth was found within groups in all the canonical analyses performed.

In the second comparison, histologically normal jejunal biopsies from the 'control' group were compared with histologically 'normal' adult tissues. The comparison was made using the biopsies from the seven healthy adult volunteers (Fig. 3) and also all 14 histologically normal adult biopsies (Fig. 4). Using all 14 adults (Fig. 4), a discrimination point at 1 would allot one adult to the child group, and vice versa. The analysis showed that separation was very largely due to crypt depth (coefficient +1.00 ) with some contribution from villus height (coefficient -0.49 ). No useful separation could be brought about using single measurements. The highest within-group correlation was -0.41 , giving the expected effect that more inflammatory cells were associated with shorter villi.

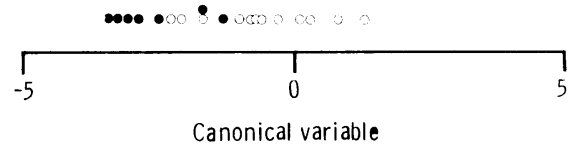

Fig. 3 Comparison of histologically normal volunteer adults with histologically normal 'control' children.

Canonical variable $=-0.00887 \mathrm{~V}+0.0400 \mathrm{C}-0.0400 \mathrm{E}$

$-0.0466 \mathrm{~T}+0.0000890 \mathrm{I}_{\mathrm{v}}$

children; $\bigcirc$ adults

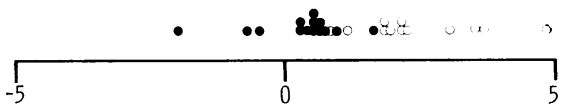

Canonical variable

Fig. 4 Comparison of histologically normal adults with histologically normal 'control' children.

Canonical variable $=-0.0141 \mathrm{~V}+0.0358 \mathrm{C}-0.0987 \mathrm{E}$

$-0.0134 \mathrm{~T}+0.000139 \mathrm{I}$ 、

children; 1 adults

\section{Discussion}

The data presented here are in broad general agreement with previously published results. A study of the extensive literature on adults ${ }^{3-5} 720212326$ shows that there is considerable variation between different studies. This could be due to either variations in the populations studied or variations in technique.

There are few studies on children with which our results can be compared. Jos ${ }^{14}$ studied biopsies taken from 14 healthy children aged between 8 months and 16 years. His figures were: villus height $400 \mu \mathrm{m}$ (range 345-515), enterocyte height $34 \mu \mathrm{m}$ (range 31-38). Our 'control' children gave a mean of $304 \mu \mathrm{m}$ for villus height and $32.3 \mu \mathrm{m}$ for enterocyte height. Iyngkaran and others ${ }^{27}$ regarded a $\mathrm{VH} / \mathrm{CD}$ ratio of $3: 1$ or more as normal in children, but in none of our children was this value reached: the highest VH/CD ratio was $2 \cdot 7: 1$. We know of no previous published data on crypt depth in children. A number of reports ${ }^{28-30}$ on theliolymphocyte counts were comparable with ours, but a recent study ${ }^{31}$ shows that caution is needed in interpreting these as they are affected by the choice of denominator against which they are measured.

The purpose of this study was to examine the concept of 'histological normality' in the jejunal biopsies of children. For ethical reasons we were not able to biopsy entirely healthy children, but assuming that our 'control' group is representative of children without gut involvement, it is clear that there are important differences between biopsies of healthy adults and healthy children. Thus, in the latter, the villi were shorter and the crypts deeper, causing a 
highly significant difference in $\mathrm{VH} / \mathrm{CD}$ ratios. There were also increased inflammatory cell counts in children, significant at the $5 \%$ level. In all these measurements there was substantial overlap, but 30 out of the $42(71 \%)$ crypt depths for children lay outside the adult range, as against $19(45 \%)$ of the villus height measurements. Thus a proportion of the biopsies from 'healthy' children were abnormal by adult criteria.

There are two approaches when considering the differences between adults and children. Either the 'normal' small intestine in a child is different from that in an adult simply because of age differences, or a proportion at least of 'clinically normal' children have an abnormal small intestine (due perhaps to an increased incidence of gut infections or transient food intolerances). Thus the situation in the child may be analogous to the minor gut abnormalities seen in healthy adults resident in the tropics. ${ }^{32} 33$

The morphometric definition of N or PVA could readily be achieved by discriminant analysis. Overlap between patient categories often makes division into groups by any single variable impossible. In this study it was possible to translate histological experience of subjectively classifying children's jejunal biopsies as N or PVA into a single canonical variable, incorporating data from measurement of villus height, crypt depth, enterocyte height, and theliolymphocyte and inflammatory cell counts. That it was possible to do this shows that the data were not grouped at random. However, the boundaries might not have been correctly drawn. That they were correctly drawn is suggested by a previous study ${ }^{34}$ in which a highly significant increase $(\mathrm{P}<0.001)$ of $\operatorname{IgA}$ plasma cell counts was found in PVA in children. Rather than extending the category of 'normal histological appearance' in children, it is better to say that about $40 \%$ of healthy children do not have a histologically 'normal' (N) biopsy.

The subjective grading of children's jejunal biopsies is fairly reliable provided the pathologist has considerable experience with mucosal biopsies ${ }^{3536}$ and the orientation of the specimen is correct. ${ }^{37}$ For those with less experience, morphometric measurements can be useful but the 'norm' must be established separately in each histological department. Morphometry in this study has helped to establish the difference between the 'norm' of adults and that of children and also the fact that a partial villous atrophy in children is found in the absence of gastrointestinal symptoms and, conversely, a normal mucosa in children can be associated with the presence of diarrhoea.

Dr FJ Penna acknowledges with gratitude the receipt of a scholarship from the Conselho Nacional de
Desenvolvimento Cientifico e Tecnologico (of Brazil).

\section{References}

${ }^{1}$ Shiner M, Doniach I. Histopathological studies in steatorrhoea. Gastroenterology 1960;38:419-40.

2 Madanagopalan N, Shiner M, Rowe B. Measurements of small intestinal mucosa obtained by peroral biopsy. Am J Med 1965;38:42-53.

${ }^{3}$ Roy-Choudhury D, Cooke WT, Tan DT, Banwell JG, Smits BJ. Jejunal biopsy: criteria and significance. Scand J Gastroenterol 1966;1:57-74.

${ }^{4}$ Stewart JS, Pollock DJ, Hoffbrand AV, Mollin DL, Booth CC. A study of proximal and distal intestinal structure and absorptive function in idiopathic steatorrhoea. $Q J$ Med 1967;36:425-44.

${ }^{5}$ Burhol PG, Myren J. Jejunal biopsy findings in healthy young men. Scand J Gastroenterol 1968;3:346-50.

- Pollock DJ, Nagle RE, Jeejeebhoy KN, Coghill NF. The effect on jejunal mucosa of withdrawing and adding dietary gluten in cases of idiopathic steatorrhoea. Gut 1970;11:567-75.

${ }^{7}$ Scott BB, Losowsky MS. Patchiness and duodenal-jejunal variation of the mucosal abnormality in coeliac disease and dermatitis herpetiformis. Gut 1976;17:984-92.

${ }^{8}$ Solhaug JH. Morphometric studies of the small intestine following jejuno-ileal shunt operation. Scand $J$ Gastroenterol 1976;11:155-60.

- Reunala T. Gluten-free diet in dermatitis herpetiformis. II. Morphological and immunological findings in the skin and small intestine of 12 patients and matched controls. Br J Dermatol 1978;98:69-78.

10 Weibel ER. Principles and methods for the morphometric study of the lung and other organs. Lab Invest 1963;12: 131-55.

11 Dunnill MS, Whitehead R. A method for the quantitation of small intestinal biopsy specimens. J Clin Pathol 1972; 25:243-6.

12 Chapman BL, Henry K, Paice F, Stewart JS, Coghill NF. A new technique for examining intestinal biopsies. Gut 1973;14:905-9.

${ }^{13}$ Slavin G, Sowter C, Robertson K, Macdermott S, Paton K. Measurement in jejunal biopsies by computer aided microscopy. J Clin Pathol 1980;33:254-61.

14 Jos J. La biopsie de la muqueuse intestinale chez l'enfant. Etude des syndromes de malabsorption. Paris: R Foulon et $\mathrm{Cie}, 1962$.

${ }^{15}$ Cameron AH, Astley R, Hallowell M et al. Duodenaljejunal biopsy in the investigation of children with coeliac disease. $Q J$ Med 1962;31:125-40.

16 Hamilton JR, Lynch MJ, Reilly BJ. Active coeliac disease in childhood. $Q J$ Med 1969;38:135-58.

${ }^{17}$ Risdon RA, Keeling JW. Quantitation of the histological changes found in small intestinal biopsy specimens from children with suspected coeliac disease. Gut 1974;15:918.

${ }^{18}$ Meinhard EA, Wadbrook DG, Risdon RA. Computer card morphometry of jejunal biopsies in childhood coeliac disease. J Clin Pathol 1975;28:85-93.

19 McNeish AS, Anderson CM. Coeliac disease. The disorder in childhood. Clin Gastroenterol 1974;3:127-44.

${ }^{20}$ Swanson VL, Thomassen RW. Pathology of the jejunal mucosa in tropical sprue. Am J Pathol 1965;46:511-51.

21 Ferguson A, Murray D. Quantitation of intraepithelial lymphocytes in human jejunum. Gut 1971;12:988-94.

${ }^{22}$ Ferguson R, Asquith P, Cooke WT. The jejunal cellular infiltrate in coeliac disease complicated by lymphoma. Gut $1974 ; 15: 458-61$. 
${ }^{23}$ Holmes GKT, Asquith P, Stokes PL, Cooke WT. Cellular infiltrate of jejunal biopsies in adult coeliac disease in relation to gluten withdrawal. Gut 1974;15:278-83.

${ }^{24}$ Armitage P. Statistical methods in medical research. Oxford: Blackwell Scientific Publications, 1971:332-43.

${ }^{25}$ Fraser P, Healy M, Rose N, Watson L. Discriminant functions in differential diagnosis of hypercalcaemia. Lancet $1971 ; 1: 1314-9$.

${ }^{26}$ Ferguson R, Allan RN, Cooke WT. A study of the cellular infiltrate of the proximal jejunal mucosa in ulcerative colitis and Crohn's disease. Gut 1975;16:205-8.

27 Iyngkaran N, Robinson MJ, Prathap K, Sumithran E, Yadav M. Cows' milk protein-sensitive enteropathy. Combined clinical and histological criteria for diagnosis. Arch Dis Child 1978;53:20-6.

${ }^{28}$ Ferguson A, McClure JP, Townley RRW. Intraepithelial lymphocyte counts in small intestinal biopsies from children with diarrhoea. Acta Paediatr Scand 1976;65: 541-6.

${ }^{29}$ Mavromichalis J, Brueton MJ, McNeish AS, Anderson CM. Evaluation of the intraepithelial lymphocyte count in the jejunum in childhood enteropathies. Gut 1976;17: 600-3.

${ }^{30}$ McNicholl B, Egan-Mitchell B, Fottrell PF. Variability of gluten intolerance in treated childhood coeliac disease. Gut 1979;20:126-32.
${ }^{31}$ Guix M, Skinner JM, Whitehead R. Measuring intraepithelial lymphocytes, surface area, and volume of lamina propria in the jejunal mucosa of coeliac patients. Gut 1979;20:275-8.

${ }^{32}$ Baker SJ. Subclinical intestinal malabsorption in developing countries. Bull WHO 1976;54:485-94.

${ }^{33}$ Lindenbaum J, Gerson CD, Kent TH. Recovery of smallintestinal structure and function after residence in the tropics. I. Studies in Peace Corps volunteers. Ann Intern Med 1971;74:218-22.

${ }^{34}$ Maffei HVL, Kingston D, Hill ID, Shiner M. Histopathologic changes and the immune response within the jejunal mucosa in infants and children. Pediatr Res 1979; 13:733-6.

${ }^{35}$ de Peyer E, France NE, Philips AD, Walker-Smith JA. Quantitative evaluation of small intestinal morphology in childhood. Acta Paediatr Belg 1978;31:173.

${ }^{36}$ Manuel PD, Walker-Smith JA, France NE. Patchy enteropathy in childhood. Glit 1979;20:211-5.

37 Perera DR, Weinstein WM, Rubin CE. Small intestinal biopsy. Hum Pathol 1975;6:157-217.

Requests for reprints to: Mr D Kingston, Division of Clinical Sciences, Clinical Research Centre, Watford Road, Harrow, Middx HA1 3UJ. 